\title{
Analysis on the Image of Quentin in William Faulkner's the Sound and the Fury
}

\author{
Man Liu \\ School of Foreign Languages \\ Changchun Institute of Technology \\ Changchun, China
}

\begin{abstract}
In the Sound and the Fury written by William Faulkner, the protagonist Quentin is a sensitive young man of the Compson family. He is caught in a dilemma both reflecting historical reality and having hope for human spirit. Quentin chooses to die in the end, letting himself exceed thought and pursing spiritual regeneration. It is an everlasting spirit with no fear of destruction and beyond physical life. This article analyzes from Quentin's spiritual world, character flaw and death.
\end{abstract}

Keywords-William Faulkner; the Sound and the Fury; image analysis

\section{INTRODUCTION}

In 1929, Faulkner finished his first work, the Sound and the Fury, in which he spends the most time and with which he is most satisfied. The Sound and the Fury describes a tragic story of the Compsons, a downfallen landlord family in Southern America. The novel begins with internal monologues of eldest son Quentin and his brothers Jason and Bangui, takes Katie's degeneration as the clue and ends up with conclusion from the perspective of a black maid. The part describing Quentin in the novel is set on Jun. 2, 1910. It narrates Quentin's activities in this day, showing Katie's degeneration and Quentin's despair through his ideological activities. In this novel, William Faulkner sets this story is happened in Southern America. He devotes considerable attention to tragedy color of human nature. In the materialistic social background at that time, Faulkner deeply reflects through this work, expressing people's kindness in a painful and deep way by describing the image of Quentin. It appeals to readers very skillfully and arouses strong resonance. In this novel, Quentin's body is described as "only an empty hall with many names of failure resounding, and injured soul fills up his heart". As a young quick-witted man, Quentin doesn't grow up happily. Instead, the stifling feeling makes him fight alone and in a dilemma to choose between nice ideal world and dirty real world. Quentin's despair and worry shows his helplessness. It is because Quentin is influenced by the family and must accept family rules and tradition of aristocrats in Southern America and put family honor in the first place. It is the first time that William Faulkner describes spiritual outlook of American young people after war in an artistic way.

\section{DEFECTS OF SPIRITUAL WORLD}

The Southern America has been always called Bible belt because of historical factor. It is greatly influenced by thoughts of the Dark Ages. People's thoughts are very traditional and conservative. Puritanism with Calvinism as the core is the complex of society, economy and culture of Southern America, supporting slavery and racism and controlling people's thoughts in those areas. It forms a complete and systematic puritan moral standard, clearly pointing out the principles and mutual relation between people. The Sound and the Fury exactly describes the story of three sons in Compson family, a declining aristocrat in Southern America, with one of the protagonist named Quentin, who is also mainly analyzed in this paper.

It is Quentin's deep-rooted traditional thoughts that lead to his suicide. William Faulkner once said Quentin doesn't like his sister's flesh but cherishes honor of the Compsons. He is the representative of declining aristocrat in Southern America, having very strong southern traditional consciousness, being proud of history and honor of his family and living a brilliant life. However, the change of reality makes Quentin unable to bear great pressure and anguish so that he has no choice but to die. Quentin's suicide and Katie's virginity lost are only the blasting fuses. The true cause of his tragedy is his traditional thought. He lacks energetic world outlook, the outlook on life and values. So to speak, the figure of Quentin is a classic representative of degenerate young people. We can intuitively see the hopeless situation of American southern aristocrat and the spiritual crisis of American young people after the First World War.

If we say Quentin's spiritual world is built by nihilism, the timid and incompetent character is the direct factor causing his tragedy. The timid image directly embodies on him because he longs for love but has no courage to defend it. Quentin wants to duel with Dalton and revenge for his sister by defeating him and win over his dignity, but Dalton looks down upon Quentin who even has no courage to hold the gun when Dalton passes it to him. Timid and thin Quentin tries to beat Dalton. Instead, he is seized and controlled by Dalton. It makes Quentin ridiculous and poor and becomes his everlasting shame.

Fund: This article is the phased achievement of Jilin province social science fund, project number: 2016B335 


\section{FEAR OF TIME AND CHANGES}

Quentin confines himself in time and fails to take changes and development of reality as life principle because life represents change. Therefore, Quentin fears life and finally puts an end to his life. His father's attitudes toward life greatly influence his thought. Quentin fears time and even fights against time. He refuses to accept the existence of tomorrow and future. He cannot bear it because, for Quentin, tomorrow and future is the result of changes in time and reality. In this novel, Quentin says he has been caught in the past time since the beginning. His thoughts and behaviors are controlled by things in the past on which he survives. Quentin misses the past time, so that he feels anxious about the "thing" of time, even hoping to stop the passing of time with his own strength. At the beginning of the first part, Quentin breaks the watch given by his grandfather into pieces after fierce ideological struggle. At this time, Quentin thinks of what his father tells him repeatedly: I give this watch to you, not requiring you to remember time but hoping you can forget time sometimes instead of putting all energies in conquering time because you can never conquer it. But Quentin doesn't take his father's advice. He thinks time will stop if he breaks the watch into pieces. In reality, it only stops the pointer instead of time. In the end of this part, Quentin has no choice but to die in order to stop the time. Therefore, the death of Quentin is inevitable. Tragically, Quentin will never understand and his death cannot impede the passing of time.

Furthermore, Quentin's fear and anxiety of life also shows on the fear of sex. He fears time and changes, ignoring the transition of his sister Katie from childhood to maturity. He thinks it is the best to keep the thought that his sister is still in the juvenile state. He feels pained for his sister's virginity lost and degeneration and even becomes twisted. It is because he doesn't regard her normal living needs as human nature. On the contrary, he takes Katie's virginity as symbol of the Compsons' honor and her virginity lost insults the family honor. Quentin's attention for his sister Katie reflects his helplessness in facing inevitable changes in life. He puts an end to his life so as to furthest avoid reality and changes. This is Quentin's compromise for changing life and historical development but it is consequent and vain.

\section{QUENTIN'S DEATH}

As it were, Quentin's suicide is forced by time. He thinks time doesn't pass in straight line. Instead, time represents the past. Quentin fails to admit the existence of today and future. The past never dies because it has been always in Quentin's thought, controlling his real life. Therefore, when Quentin dies, the watch, the sun and the shadow form a recombination time, showing Quentin is reluctant to part with the tradition in Southern America and suffers from seeing the collapse of traditional ideas and rules before his death. When passing the ancestral watch to him, Quentin's father says, this watch represents the grave of all hopes and desires. Now I give you the watch with which you can easily understand the reducto absurdum proving the mistake of human experience. From that time, Quentin begins to fear time. Although Quentin doesn't believe his father's opinion, "Jesus doesn't die on the cross but is tortured by the grating making by small gears to death", time leaves indelible shadow in his mind. Quentin thinks time connects traditional myth in the south with social reality. It causes the collapse of value system established by the southerner in hundreds of years, lets the shipshape southern society become dirty, causing his sister's leaving and the downfall of his family. Therefore, Quentin dislikes and fears time. For many times, he wants to break the watch into pieces but never put it into practice. His father once said time is dead when the small gear rotates; and time will come alive when the watch stops. When Quentin decides to suicide, time resembles a horn of death calling him so that he looks at the watch for dozens of times in very short time. Quentin will hear the sound of pointer when he is lost in thought every time, as though the time urges him to die. In the end, with the final sound, Quentin tidies up his things, puts on his hat and walks slowing towards the river, meeting the arrival of death.

Quentin is dead with reluctance of losing the tradition in Southern America, anxiety for collapse of traditional system, heavy and unspeakable pain as well as inanition and loneliness because of destruction of survival foundation. However, the death of Quentin changes neither the ending that the Compsons walk towards downfall nor the collapse of southern traditional system. His death is only a miserable elegy and will be forgotten by us with the emergence of new generation of southerners.

\section{CONCLUSION}

To sum up, with deep historical origin, the tragedy of Quentin is tragedy of both the Compsons and the society in Southern America under social background at that time. With radical changes of social environment and collision of old and new thoughts, the aristocrats of Southern America is at a loss. The spiritual degeneration of some people is inevitable because the social status of downfallen noble families falls. All in all, the downfall of Southern America is the fading of economic basis and political system as well as the collapse of traditional moral models.

\section{REFERENCES}

[1] Huang Ting. Discussion on Thinking of the Sound and the Fury on the Survival Predicament of Modern People [J], Journal of Heilongjiang College of Education, 2014(08), 28

[2] Sun Yibing. Comparative Study of the Sound and the Fury and Red Poppies [J], Modern Chinese Literature Studies, 2014 (04): 15

[3] [3]Gao Xueyan. Application of Free Association in Faulkner's the Sound and the Fury [J], Journal of Tianjin Vocational Institutes, 2014 (01): 31 . 